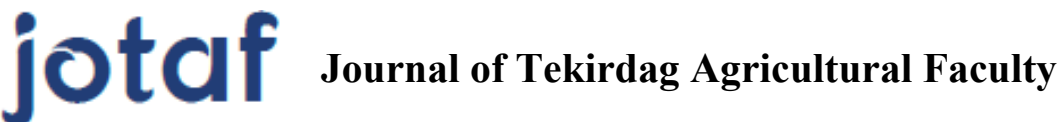

Tekirdağ Ziraat Fakültesi Dergisi

Mayis/May 2021, 18(2)

Başvuru/Received: 16/03/20

Kabul/Accepted: $10 / 02 / 21$

DOI: $10.33462 /$ jotaf. 704880

http://dergipark.gov.tr/jotaf

http://jotaf.nku.edu.tr/

ARAŞTIRMA MAKALESI

RESEARCH ARTICLE

\section{Investigating the Causes of Entrepreneurs Failure to Start-up Greenhouse Business in Isfahan Province, Iran}

\author{
Masoud RAMEZANI ${ }^{1}$, Abdolhamıd PAPZAN ${ }^{2 *}$
}

\begin{abstract}
Despite the impact of entrepreneurships on economic development, it has not received much attention over the last few decades. Most studies in the field of entrepreneurship have been based on the experiences of successful entrepreneurs. Although the success and failure of entrepreneurs are two sides of the same coin, studying the causes of entrepreneurial failure provides us with much more important information for analyzing the entrepreneurial ecosystem in a country. Therefore, by examining the failure of entrepreneurs, the entrepreneurial ecosystem can be changed to improve the conditions for future success of entrepreneurs. The present study examines factors caused to failure start-up greenhouse business by licensed entrepreneurs in province of Isfahan located at central part of Iran. This study considers population who obtained license to start greenhouse business but failed to do so at last. This study applied qualitative research technique and related data were collected through semi-structured telephone interviews with totally 450 interviewee and 264 of them participated in the study. To analysis the collected data, the structural content analysis technique of grounded theory was applied. Due to importance of factors, vocabulary counting technique was applied. As a result, 575 Barriers are expressed by entrepreneurs. At the open coding stage, the extracted phrases are integrated in 19 terms of meaningful expressions by integrating the same items and removing repetitive cases. At the axial coding stage, 19 integrated concepts are obtained. Subsequently, the extracted phrases create six main factors. At the selective coding stage, the entrepreneurs' basic barriers are categorized into three categories: Human Barriers, Economic barriers, Infrastructure facilities and supportive policies. This study well revealed that weak infrastructure facilities, poor supportive system, economy barriers and problems with human resource barriers respectively had powerful deterrent factors which caused license holders to give up starting a greenhouse business.
\end{abstract}

Keywords: Failure of Entrepreneurs, Startup Greenhouse Business Failure, Sustainable Agriculture, Isfahan Province

\footnotetext{
${ }_{1}$ Masoud RAMEZANI, Department of Agronomy, Faculty of Agriculture, Isfahan (Khorasgan) Branch, Islamic Azad University, Isfahan, Iran. E-mail: m.ramezani@khuisf.ac.ir (iD) OrcID: 0000-0002-1941-3759

${ }^{2}$ Corresponding Author: Abdolhamid PAPZAN, Department of Agricultural Extension and Education, College of Agriculture, Razi University, Kermanshah, Iran. E-mail: Abdolhamid.Papzan@gmail.com (iD) OrcID: 0000-0002-7159-899X

Atıf/Citation: Ramezanı, M., Papzan A. Investigating the Causes of Entrepreneurs Failure to Start-up Greenhouse Business in Isfahan Province, Iran. Tekirda $\breve{g}$ Ziraat Fakültesi Dergisi, 18 (2), 187-196.
}

CBu çalışma Tekirdağ Namık Kemal Üniversitesi tarafından Creative Commons Lisansı (https://creativecommons.org/licenses/by-nc/4.0/) kapsamında yayınlanmıștır. Tekirdağ 2021 


\section{Introduction}

In recent decades, sustainable agriculture has been highly valued in considered of development programs, due to environmental issues. Generally, Sustainable Agriculture has two fundamental goals of maintaining agricultural production levels with benefit of reducing harmful environment impacts (Khaton Abadi and Amini, 1996). In all local farming systems, to reduce dependency on low-inputs of environment and increase its effective use is one the most important requirements. Small family farms, as in Turkey, constitute the main structure of Iran's agriculture. In such circumstances, special attention should be paid to increasing yield per unit area to improve people's livelihoods (Özpınar, 2017). Climate change is already affecting agriculture; with considerable damages unevenly distributed across the world including Iran is not exempt from this. Because of Iran's climate condition which drought is one of its consequences, the country is facing with water resources constraints. Moreover, Agriculture in Isfahan province has faced with irreparable damage recently, because of factors such as; unwisely human interference, incorrect water resources management, and extensive exploitation of underground resources, inappropriate cultivation patterns, incorrect cropping systems and improper design of irrigation (Ramezani and Papzan 2019). On the other hand, sustainable food security is becoming increasingly important because of growing urban population.

One of the offered solutions to cope with these problems is greenhouse cultivation expansion. Greenhouse cultivation created possibility to use dense cultivation, continuous production, increased productivity in limited water, soil, and manpower resources with controlling environmental factors at the same time. Development of greenhouse crops to meet the growing food needs of the country and the water restrictions of the region has been considered by the Agricultural Jihad Organization and Isfahan Province authorities.

Despite the need to greenhouses expansion across the province, unfortunately more than half of those who have received greenhouse permits have never set up their own greenhouses, in other words; they have failed soon at the early stage in this way to start-up a greenhouse business $(\mathrm{GhB})$. This study investigates the factors affecting the failure of greenhouse entrepreneurs in Isfahan province and seeks to find the right answer to the question of why greenhouse applicants have been reluctant to set up their greenhouses after spending time and money and obtaining an establishment permit, which usually takes between one and two years.

Identifying main causes and reasons to stop setting up greenhouses not only prevent wasting time and capital of applicants but also enable authorities and planners in order to make proper decisions in Isfahan province.

In particular, definitions of business "disappearance", "closure", "exit", and "failure" are confusing and often overlapping. Business "disappearance" could be derived from seizeur, integration or optional closure (Cardozo and Borchert, 2004). Business "closure" means non-survival, instability and business interruption. The term "exit" can be used to exit a business in a particular market or to produce a particular product or to terminate an entrepreneur's participation in a business (Stokes and Blackburn, 2002)."Failure" means being defeated, failing to achieve a goal, failing to do the job, failing to reach the desired goal, and being bankrupt due to inability to pay the debt. Failure is not about liquidating a business, but about failing to meet predetermined goals at the time of setting up or managing a business (Cannon and Edmondson, 2001, 2005; Sitkin, 1992). According to abovementioned definitions; the study population failed to achieve their goals so it can be said that the study community failed to start-up GhB.

Few studies have been conducted on failure compared to success (Whetten, 1980), new businesses are constantly looking for successful business models. Moreover, failure studies have been considered due to failures and avoiding repetition of mistakes (Williamson, 1985), the investigation about failure has great importance and should be done with the same intensity as the investigation about success (Nonaka and Takeuchi, 1996; Sheppard and Chowdhury, 2005).

There are many causes contributing to the failure of entrepreneurs. Some consider individual factors to be involved and believe that entrepreneurs themselves have a significant impact on survival and growth of start-up (Chell et al., 1991; R Bellu, 1993). Human capital factors such as age, education, gender and ethnicity are essential to growth (Cooper et al., 1994; Wiklund and Shepherd, 2001). "Inappropriate financing" is one of the factors that many scholars have emphasized on its importance (Bruno et al., 1992; Hodgetts and Kuratko, 2001; Longenecker et al., 1999; Zacharakis et al., 1999). Financial problems include lack of attention to proper financing and lack of 
cash management for survival and business expansion. Understanding the technical and financial feasibility and identifying potential customers is crucial for the proper development of a business plan for the survival and growth of initiatives (Castrogiovanni, 1996; Hansen, 1995).

Women entrepreneurs in Kermanshah province are facing with financial barriers, administrative bureaucracy barriers, complex procedures to obtain license, shortage of capital, lack of access to financial resources, high production costs, banks' uncertainty, investors' uncertainty, high raw material costs, marketing, knowledge, skill, cultural and personality barriers (Ghambarali and Rostami, 2015). Notash (2014) identifies that lack of business knowledge, little experience, lack of skill, inappropriate marketing skill, inadequate partnerships, lack of anticipation of alternatives, financial barriers, repeated errors, and unfavorable business environment are the roots of the failure of entrepreneurs. Najafi and Safa (2014) cited that factors such as lack of proper businessplan, lack of experience and expertise in rural areas, lack of access to rural markets, lack of access to info rmation and information resources, lack of financing for business investment, local jobs and law barriers are the major obstacles and challenges for entrepreneurship development in rural areas in rural entrepreneurial home businesses.

Some people consider the support system as a business failure factor. A small business development support system that can provide educational services, technical advice, supportive infrastructure, access to capital, and a legal environment is essential (Valentinov, 2007). Markley and Dabson (2008) considers the issue of partnership and how to select shareholders or owners and how to work together to create and run a business. Doing mistakes in partnership is one of the most important problems that cause entrepreneurs failure (Ghambarali and Rostami, 2015).

Arasti and Gholami (2010) has taken into accounts factors such as weaknesses in human resource management, cash flow and accounting problems, unrealistic project evaluation, technical problems in the production process, lack of support of family and friends, corruption and the need to use illegal relationships and practices, inappropriate financing by investors and banks, government laws and regulations incompatible with entrepreneurial activities, inappropriate economic climate and international developments such as the war, etc. in the failure of entrepreneurs. Walsh and Cunningham (2017) attributes the failure of entrepreneurs to inexperience, lack of financial commitment, difficulty accessing finance resources. Al-Shami et al. (2019) attributes the failure of Malaysian female entrepreneurship to personal life events, intensive competition and loan inflexibility, lack of resources, poor financial management and personal dissatisfaction with their own business performance.

In generally, according to all previous studies there are several important factors which cause to business failure such as inappropriate financial recourses, financial issues, inefficient liquidity management to survive and business development, lack of financial capital, high production costs, high costs to supply raw material, lack of appropriate business plan, unrealistic evaluation of business plan, lack of experience to select shareholders, inappropriate frustrating, lack of family support, lack of knowledge and experience, doing repeated mistakes, cultural barriers, lack of access to adequate data, complex procedure to obtain license, administrative corruption and bureaucracy, lack of supportive system for producers, no educational system, lack of technical consultancy, inappropriate regulation toward entrepreneurship, international condition such as sanction and war. The main purpose of this study is qualitatively to investigate the reasons for not starting greenhouses by entrepreneurs in the agricultural sector in Isfahan province.

\section{Materials and Methods}

The purpose of this study is practical and it is qualitative in nature. Due to the lack of information and resources on the cause of the failure of greenhouse entrepreneurs, it is necessary to address this issue from different perspectives. The grounded theory approach will be useful for identifying processes where there is insufficient knowledge (Bazargan, 2019). Therefore, in this study, grounded theory, systematic approach was used. This approach has been proposed by Strauss and Corbin (Corbin and Strauss, 1990).

The study population includes of individuals who get related approvals between 2009 - 2017 but gave up starting to do so. Agricultural and natural resources engineering Organization of Isfahan extracted greenhouse statistics from the information available in their file and provided it to research team. In Isfahan province, 1012 permission to startup vegetable $\mathrm{GhB}$ have been issued which 471 cases started up their own business and obtain utilization permission as well. 91 cases are setting up their Greenhouse Business, while 450 cases failed to start up $\mathrm{GhB}$ and gave up to do so, 
The data collection tool is a semi-structured interview. Due to the geographical extent of the province, the distribution of the study population at the provincial level, lower costs and improved quality of information gathering, faster access to people, greater convenience of the interviewer and the interviewee, telephone interviewing was used to gather information. For this study, 264 individuals were studied. To analyze the data after assigning the code to each interviewee, the interviews implemented the words, their meanings and their relevance in terms of repetition rate, number of words, words, metaphors and idioms used in sentences and their repetition rate, counting were made to discover patterns in the utterances. (Puppis, 2019). Open coding was done for the collected data on the basis of allocation of conceptual tags. In the open coding phase, 575 quotes and 48 concepts were identified and categorized into 19 codes. In this section, only open codes derived from data were presented in the form of concepts. The codes were reviewed and finally coded based on the research-driven phenomenon that led to the failure of greenhouse entrepreneurs. Axial Coding (Summarizes 6 categories and identifies the relationship between the categories and determines the underlying causes, describing the causal conditions), and selective coding (to communicate between axial and other categories and modify them) have been used. (Corbin and Strauss, 2014)

In the structural analysis of the transcribed text, the textual structure of the interview text was used to confirm the findings using triangulation method and the results were confirmed by the statistical community and knowledgeable people in this field.

\section{Results and Discussion}

Since study population is 264 people, at first it seems necessary to consider the individual characteristics of the respondents and then the reasons for not setting up a greenhouse. According to research findings, 95.1 percent of greenhouse approvals have been issued to male applicants. It seems that GhB is men owned business. During the interview it was revealed that the percentage of women who tried to set up a greenhouse by themselves is even lower. It was explored that if any approval was issued to women it was mainly due to ownerships of the land.

39.4 percent of approval was related to start-up small size $\mathrm{GhB}$ (less than $4000 \mathrm{M}^{2}$ ), 50.8 percent of approval to start-up average size greenhouse business (between 4000 to $8000 \mathrm{M}^{2}$ ) and 9.8 percent of approval to start-up big size $\mathrm{GhB}$ (more than $8000 \mathrm{M}^{2}$ ). Since more issued approvals rate are related to average size $\mathrm{GhB}$, it means that most applicant to start-up GhB are from middle class people.

\subsection{Result of coding process:}

Interviewees were asked to give explanation to give up starting GhB and totally 575 separate reasons were represented. 48 conceptual sentences were identified during open coding process and 19 integrated subjects were identified during axial coding process and merging the same concepts and removing repetitive cases, finally the main variables were identified during selective coding process which included human barriers, economic barriers, supportive barriers, infrastructure barriers. The results of the coding process are presented in Figure 1. 


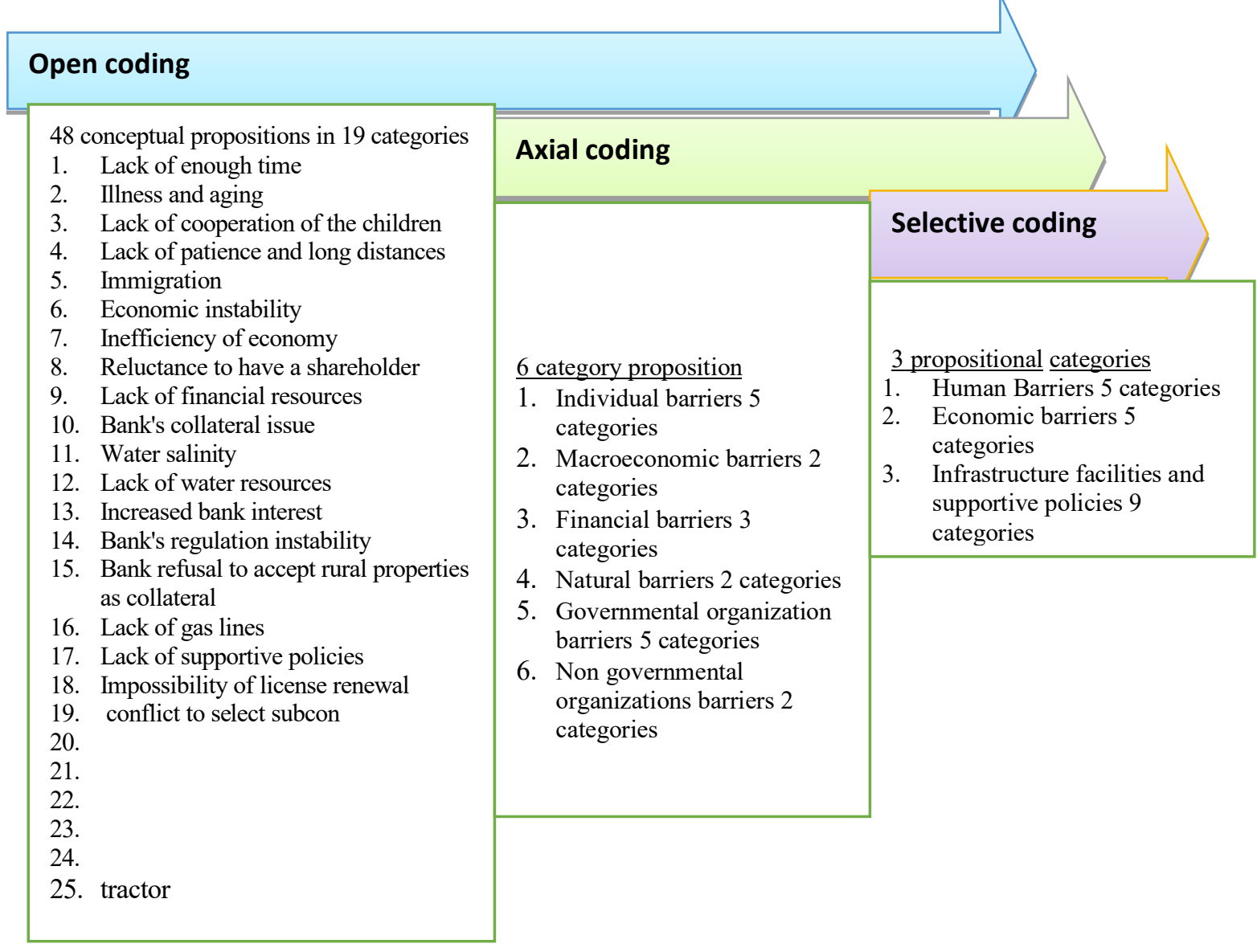

Figure 1. The results of the coding process

According to received data, study population volume, rate of repeated responses in this section, in order of importance and weight, each factor will be evaluated separately:

\subsection{Infrastructure facilities and supportive policies}

This indicator would be investigated by organizations and natural barriers, which organization has two different views of governmental organizations (GO) barriers and Non-governmental organization (NGO) barriers as following:

\subsubsection{Governmental organization barriers}

Bank's profit regulation instability, complexity in bank's regulations, bank refusal to accept rural or common properties as collateral, lack of infrastructure facilities such as gas lines, lack of supportive policies of production business are included $\mathrm{GO}$ barriers.

Results of word counting show that bank's totally is a serious deterrent to start-up GhB with 33.4 percent of frequency. They refuse to accept properties as collateral to loan assignment. This factor has important effect with 24.3 percent. Unfortunately, Operating Banks refuse to accept some part of greenhouse's property as collateral unlike to industrial projects. On the other hand, they refuse to accept rural land and common properties, on the contrary, Banks accept urban properties, because these properties are easy to sale. Moreover, this will serve the interests of banks, but it can never lead to agricultural growth and prosperity. Lack of valuation of agricultural lands form bank point of view causes that farmers buy land or urban properties and they invest in nonproductive urban sectors instead of investing in rural production which it would multiply the lack of development in rural regions. Also increasing the bank profit caused to give up starting up this business for 4.7 percent of farmers. Complexity and bureaucracy of banks regulation has 4.3 percent frequency as well. 
Lack of gas lines and lack of government supportive policy toward production accounts for 3 percent of failure to start up GhB separately, since the cost of greenhouse gas heating is considerable, lack of gas lines to failure is reasonable. Due to the reduction in greenhouse gas heating costs by one-second or one-third compared to other fossil fuels, energy accounts for a significant portion of the cost of production, so the lack of greenhouse startups seems reasonable due to the lack of gas.

\subsubsection{Nongovernmental organizations barriers}

Impossibility to extend approvals of starting greenhouses and conflict with Agricultural and Natural resources engineering organization of Iran are two most important factors, with frequency of 0.7 and 0.5 respectively. It should be noted that it is possible to extend approval for just 3 years which is legal and if greenhouse was not started by approval applicants, all approval procedure must be done again.

\subsubsection{Natural Barriers}

Natural factors such as climate change which drought is one of its consequences caused to lack of water resources and water salinity. Inhabitants of these regions who has the same challenges failed to start-up GhB. Water resources shortage with 9.4 percent and water salinity with 0.5 percent has effect on failure to start up GhB.

\subsection{Economic system barriers}

Generally, economic barriers have two different levels consist of microeconomic and macroeconomic on the way to startup GhB. Each one of factors has been considered separately as following:

\subsubsection{Financial barriers}

Financial barriers consist of Lack of financial resources, bank's collateral problem and unwillingness to have a shareholder. It should be noted that there is a narrow boundary between the lack of collateral and the refusal to accept property collateral for rural and common lands.

Inability to give proper guarantee against the bank loan would be included in financial barriers whereas refusal to accept common or rural properties by banks is an organizational barrier. According to word counting financial resources barriers, collateral and shareholder problems have 20,12 and 1.7 percent effect on failure start-up GhB respectively.

\subsubsection{Macroeconomic barriers}

These kinds of barriers explore the implications of economic instability and inefficiency of economy accounts for 7.7 and 3.8 percent of failure to start-up GhB respectively, also they have a strong cause and effect relationship with each other and are among economic variables.

\subsection{Human Barriers}

Human factors such as illness and aging, Lack of cooperation of the children with the principal in the process such as father or grandfather with license holder to take steps, long distance, lack of enough time to spend and immigration account for 2.3, 1, 0.2, 0.2 percent of failure to start-up GhB respectively.

The conceptual model of the factors effect on the failure start-up of greenhouse business has been designed in Figure 2.

Based on the word counting procedure results, lack of infrastructure facilities and supportive system has the most significant effect on failure to start-up G GhB B by 50.4 percent. In the meanwhile, the role of GO and natural factors is 39.3 percent and 9.9 percent respectively. Since, NGOs does not have much effect on the failure of GhB. Economic barriers totally contributed 45.2 percent that financial barriers have a 33.7 percent share of total and microeconomic barriers have 11.5 percent. Among all studied factors on greenhouse failure, human factor with frequency of 4.4 percent has the least effect among the other factors. In the conceptual model of this study, each factor effects directly on the failure of GhB. 


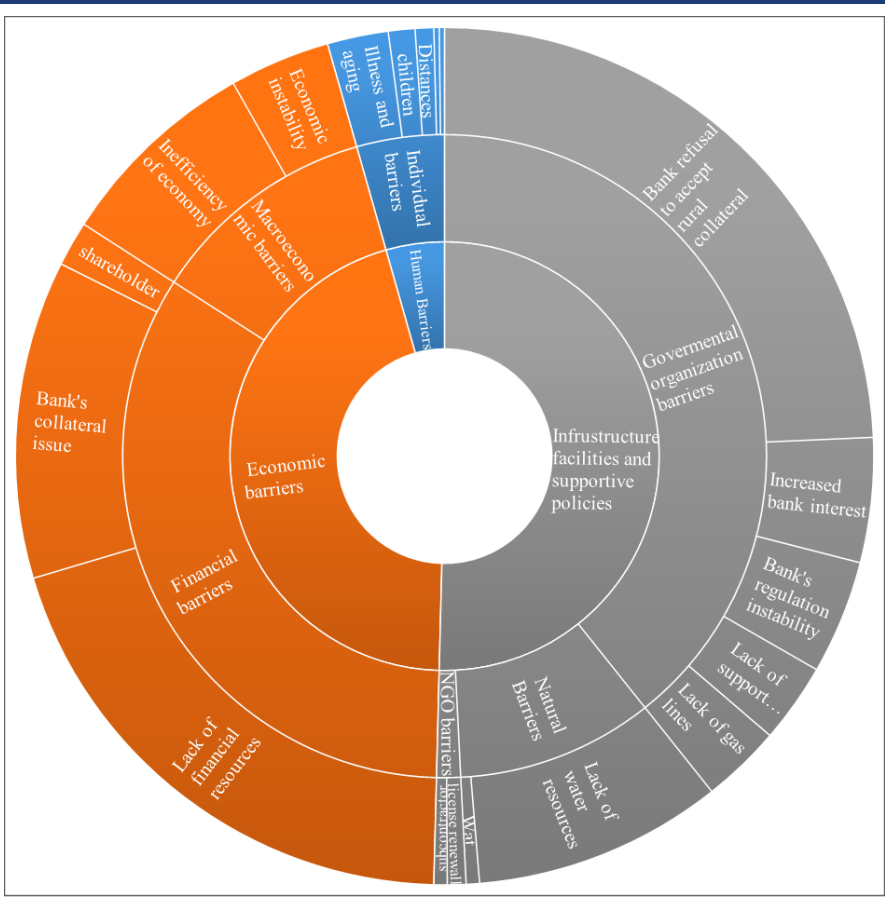

Figure 2. The conceptual model of identification and classification of the factors effect on the failure start-up of greenhouse business

\section{Conclusions}

Role of GO to failure a $\mathrm{GhB}$ was evaluated crucial and fundamental role in infrastructure facilities and supportive policies barriers. This finding is in the line with the results of the Moumeni-helali (2015) and Ghambarali's studies (2015). This factor was the first effective obstacle of start-up a GhB. In the meanwhile, operating banks had a powerful deterrent effect on rural entrepreneurs. Refusal to accept the rural properties, rural common properties and the greenhouse land as the part of the collateral have created numerous problems for applicants. Whereas in the industrial sectors, operating banks accept the land and factory as collateral even it is located in rural areas. This attitude aggravated the backwardness in agricultural sector and increased social gap between rural and urban systems. If the end goal of rural development is to prioritize the destitute people and make them empowerment and self-reliance, these measures are inconsistent with adopted policies.

On the other hand, rising Bank interest rate from 5 percent or 7 percent to 14 percent or 18 percent, which it complies with current economic condition in Iran, anyhow it cannot be properly justified because of necessity of changing production patterns and optimum use of water resources especially in areas such as Isfahan province.

It is not economically rational to provide the same pattern of bank profits for the country and for all businesses. In the meanwhile, complexity of banking regulation and bank's regulation instability have also aggravated and because of lack of agility and excessive administrative bureaucracy have made numerous problems for applicants, so that some of them leave halfway left unfinished.

Existence of gas lines is one of the most essential facilities to start-up GhB. Unfortunately, in Isfahan province greenhouse owners use neither renewable nor clean energies for energy supplying and sustainable agriculture. The lack of gas has led some greenhouses to give up start this business, which makes sense.

Shortage of government supportive system toward production sector is one of the barriers to discourage applicants to start-up GhB. The findings are complying with the explored results by Valentinov, (2007) and Markley and Dabson (2008). Unfortunately, government supportive policies for the production sector are limited to grant loan or to ask postponing farmers' debts. It is expected that government provides literally the supportive system including of various services such as education, technical advice, financial resources and moral and legal environment.

Shortage of financial resources and lack of appropriate collateral are the most important financial barriers that have been created due to lack of economic function before any implementation. Hence, before taking any action, it is a must 
to hold courses about how to have effective greenhouse cost and income, how to take procedure to take related license, how to set up green house, how to set up greenhouse and writing economic feasibility study report for applicant in order to make a realistic judgment and right decision the findings are compatible with research results of (Bruno et al., 1987; Hodgetts and Kuratko 2001; Zacharakis et al., 1999, Longenecker et al. 1999, Castrogiovanni, 1996; Hansen, 1995; Notash, 2014; Moumeni-helali, 2015, Ghambarali and Rostami, 2015; Elyasi and Notash, 2011). Unwillingness to have shareholders is another effective factor on failure to start up GhB. In the study of the reasons for the withdrawal of ten applicants for greenhouses, 9 cases were due to investor withdrawal and one case was due to withdrawal of land ownership. It seems that investors are more afraid of partnerships. It has roots into the legal matters and economic profitability of greenhouses business. Some applicants withdraw from the partnership because they are not familiar with the legal issues. The findings are compatible with the results of Arasti (2006 \& 2011), Ghambarali and Rostami (2015).

Economic factors such as economic instability and economic disadvantage have reduced the attractiveness of the GhB for investment. Policymaking, having an economic cultivation pattern, attention to market components and planning production in a way that serves the interests of the producer, can be an effective factor in attracting financial capital. Resolving this problem requires national determination and the cooperation of all agricultural authorities and stakeholders. The findings of Ghanbarali, et al, Najafi et al. also confirm these results. According to the results of the research, none of the respondents had received any training in establishing a greenhouse. In other words, education has been a forgotten element during the establishment of the greenhouse. This finding is consistent with the results of Yüksel and Yüksel (2011).

According to the research findings, focus on the four midterm strategies could increase start-up greenhouses business by $45 \%$; Acceptance of rural collateral, reducing the bank profit with priority for agricultural projects including greenhouse at the provincial level, economic stabilization in order to raise economic revenue in greenhouse activity and also banking bureaucracy reduction by providing legal and moral environment.

Based on the research findings, the following recommendation are proposed to improve the conditions for establishing a greenhouse in Isfahan province:

1. It is recommended that operating banks be more flexible in accepting rural collateral and common properties. On the other hand, in order to improve the future conditions of peasants, it is advised that the government implement a plan in order to help them to split common properties for rural areas which they have right to be supported in receiving facilities at least.

2. As the lack of gas fuel piping was an obstacle to the establishment of greenhouses, so it is recommended to make appropriate policies in the field of sustainable and clean energy use in the province. Unfortunately, at present, none of Isfahan greenhouse owners use new and clean energy. Paying attention to new and clean energy sources will have a profound impact on the economic efficiency of greenhouses in long term.

3. Since termination of partnership was identified as one of the factors for not establishing a greenhouse, It is suggested that legal and financial partnership training be provided to applicants who want to set up a greenhouse as a partnership

4. Economic factors such as market instability and economic inefficiency have reduced the attractiveness of the greenhouse establishment for investment.

5. The government and greenhouse owners are expected to provide the necessary infrustructure for economic stability and agricultural planning with proper planning.

\section{List of abbreviations}

GhB: Greenhouse Business, NGO: Non-governmental organization, GO: governmental organization

\section{Acknowledgements}

We are thankful for Agricultural and natural resources engineering Organization of Isfahan extracted greenhouse statistics from the information available in their file and provided it to research team. 


\section{References}

Al-Shami, S., Al Mamun, A., Sidek, S., Rashid, N. (2019). Causes of failure among Malaysian female entrepreneurs. Qualitative Research in Financial Markets.

Bazargan, A. (2019). Introduction to qualitative research methods and mixed conventional approach in the Behavioral Sciences. Didar book. Tehran.

Bruno, A. V., Leidecker, J. K., \& Harder, J. W. (1987). Why firms fail. Business Horizons, 30(2), 50-58.

Bruno, A. V., McQuarrie, E. F., Torgrimson, C. G. (1992). The evolution of new technology ventures over 20 years: Patterns of failure, merger, and survival. Journal of business venturing, 7(4), 291-302. https://doi.org/10.1016/0883-9026(92)90003-A

Cannon, M. D., Edmondson, A. C. (2001). Confronting failure: Antecedents and consequences of shared beliefs about failure in organizational work groups. Journal of Organizational Behavior: The International Journal of Industrial, Occupational and Organizational Psychology and Behavior, 22(2), 161-177. https://doi.org/10.1002/job.85

Cannon, M. D., Edmondson, A. C. (2005). Failing to learn and learning to fail (intelligently): How great organizations put failure to work to innovate and improve. Long range planning, 38(3), 299-319. https://doi.org/10.1016/j.1rp.2005.04.005

Cardozo, R., Borchert, P. (2004). The disappearance of business. online], http://www. babson. edu/entrep/fer/BABSON2003/II/II-P2/Chapterl. htm.

Castrogiovanni, G. J. (1996). Pre-startup planning and the survival of new small businesses: Theoretical linkages. Journal of management, 22(6), 801-822. https://doi.org/10.1016/S0149-2063(96)90037-9

Chell, E., Haworth, J., Brearley, S. (1991). The entrepreneurial personality, (16): London: Routledge.

Cooper, A. C., Gimeno-Gascon, F. J., Woo, C. Y. (1994). Initial human and financial capital as predictors of new venture performance. Journal of business venturing, 9(5), 371-395. https://doi.org/10.1016/0883-9026(94)90013-2

Corbin, J., Strauss, A. (2014). Basics of qualitative research: Techniques and procedures for developing grounded theory: Sage publications.

Corbin, J. M., Strauss, A. (1990). Grounded theory research: Procedures, canons, and evaluative criteria. Qualitative sociology, 13(1), 3-21. https://doi.org/10.1007/BF00988593

Elyasi, M., Notash. (2011). Identifying the Roots of Failure of Iranian Skilled Entrepreneurs, A Discursive Narrative View ,. the Journal of Entrepreneurship Development, 4(6), 131-149.

Ghambarali, R., Rostami, F. (2015). Identifying Challenges Faced by Women Entrepreneurs of Kermanshah Province. Journal of Entrepreneurship in Agriculture, 2(1), 1-17.

Hansen, E. L. (1995). Entrepreneurial networks and new organization growth. Entrepreneurship theory and practice, 19(4), 7-19. https://doi.org/10.1177/104225879501900402

Hodgetts, R. M., Kuratko, D. F. (2001). Entrepreneurship: A contemporary approach: South-Western/Thomson Learning.

Khaton Abadi, A., Amini, A. (1996). Management and principles of sustainable agriculture. Paper presented at the 4th Congress of Natural Sciences based on optimal energy efficiency of agriculture and Plant Breeding., Isfahan.

Longenecker, C. O., Simonetti, J. L., Sharkey, T. W. (1999). Why organizations fail: the view from the front-line. Management Decision, 37(6), 503-513. DOI: 10.1108/00251749910278023

Markley, D., Dabson, B. (2008). Creating a System of Support for Entrepreneurs and Small Businesses in Kentucky. A report to the Mountain Association for Community Economic Development. Online. http://www. maced. org/files/entrepreneurshipreport-web. pdf.

Najafi, B., Safa, L. (2014). An Investigation of Entrepreneurial Home Businesses and Obstacles and Challenges for their Development in Rural Areas. Agricultural Entrepreneurship Journal, 1(2), 61-73.

Nonaka, I., Takeuchi, H. (1996). The knowledge-creating company: How Japanese companies create the dynamics of innovation. Long range planning, 4(29), 592.

Notash, H. (2014). Developing a Framework of Entrepreneurial Learning from Failures for Iranian Habitual Entrepreneurs: A Process Approach . Journal of Entrepreneurship Development, 4(6), 131-150.

Özpinar, S . (2017). Determination of Structural Properties of Agriculture in Çanakkale . Tekirdağ Ziraat Fakültesi Dergisi , 14 (1), 0-0 . Retrieved from https://dergipark.org.tr/tr/pub/jotaf/issue/29442/315449

Puppis, M. (2019). Analyzing talk and text I: Qualitative content analysis. In The Palgrave handbook of methods for media policy research (pp. 367-384): Springer. https://doi.org/10.1007/978-3-030-16065-4_21

Ramezani, M., Papzan, A. (2019). Quality Analysis of the Problems and Barriers of Greenhouse Growers: Case Study of Isfahan Province, Iran. International Journal of Agricultural Management and Development, 9(3), 249-259.

R Bellu, R. (1993). Task role motivation and attributional style as predictors of entrepreneurial performance: Female sample findings. Entrepreneurship \& Regional Development, 5(4), 331-334. https://doi.org/10.1080/08985629300000021 
Ramezanı \& Papzan

Investigating The Causes of Entrepreneurs Failure to Start-up Greenhouse Business in Isfahan Province,Iran

Sheppard, J. P., Chowdhury, S. D. (2005). Riding the wrong wave: Organizational failure as a failed turnaround. Long range planning, 38(3), 239-260. https://doi.org/10.1016/j.lrp.2005.03.009

Sitkin, S. B. (1992). Learning through failure: The strategy of small losses. Research in organizational behavior, 14, $231-266$.

Stokes, D., Blackburn, R. (2002). Learning the hard way: the lessons of owner-managers who have closed their businesses. Journal of small business and enterprise development, 9(1), 17-27. https://doi.org/10.1108/14626000210419455

Valentinov, V. (2007). Why are cooperatives important in agriculture? An organizational economics perspective. Journal of institutional Economics, 3(1), 55-69. https://doi.org/10.1017/S1744137406000555

Walsh, G. S., Cunningham, J. A. (2017). Regenerative failure and attribution. International Journal of Entrepreneurial Behavior \& Research. https://doi.org/10.1108/IJEBR-03-2015-0072

Whetten, D. A. (1980). Organizational Decline: A Neglected Topic in Organizational Science1. Academy of Management review, 5(4), 577588. https://doi.org/10.5465/amr.1980.4288962

Wiklund, J., Shepherd, D. A. (2001). Intentions And Growth: The Moderating Role of Resources and Opportunities. Paper presented at the Academy of management Proceedings. https://doi.org/10.5465/apbpp.2001.6133075

Williamson, O. E. (1985). The economic institutions of capitalism: firms, markets, relational contracting: Free Press.

Yüksel, E. and Yüksel, A.N. (2011). Tekirdağ'da Örtüaltı Yetiştiriciliğinin Belirlenmesi . Tekirdă̆ Ziraat Fakültesi Dergisi , 8 (2), 153-159 . Retrieved from https://dergipark.org.tr/tr/pub/jotaf/issue/19042/201411

Zacharakis, A. L., Meyer, G. D., \& DeCastro, J. (1999). Differing perceptions of new venture failure: a matched exploratory study of venture capitalists and entrepreneurs. Journal of Small Business Management, 37(3), 1. 